\title{
AN EFFECTIVE SCHEDULING SCHEME FOR LIFT CLUBS
}

\author{
Dr. Willem van Wijck Pr.Eng. Ph.D. Eng.
}

\begin{abstract}
:
This paper describes a formula for scheduling the day-to-day operation of a lift club. The formula is remarkably simple, and can easily be implemented on a spreadsheet. It is also extremely flexible and can cater for almost any peculiarity that may arise. Much like a business, the lift club is viewed as an entity in its own right, rather than as a collection of individuals. The scheme can be used to generate interesting statistics such as percentage utilization of each member, average percentage utilization of all members, effective size of the lift club, etc. In addition, a graph, depicting each member's liability towards the club against time, can be generated. Finally, every member can obtain a record of his/her trip data over any specific period, which may be handy for income tax purposes.
\end{abstract}

\section{OPSOMMING:}

Hierdie artikel beskryf ' $n$ formule vir die dag-tot-dag skedulering van 'n saamryklub. Die formule is merkwaardig eenvoudig en kan maklik op ' $n$ sigblad geïmplementeer word. Dit is ook besonder buigsaam deurdat dit vir bykans enige gebeurlikheid voorsienning maak. Die voorgestelde skeduleringsmetode beskou die saamryklub as 'n entiteit in eie reg, en skeduleing word vanuit die saamryklub se oogpunt gedoen. Die skema kan gebruik word om interesante statistieke soos byvoorbeeld die persentasie benutting deur enige lid, die gemiddelde persentasie benutting deur alle lede, die effektiewe grootte van die klub, ens., te genereer. Voorts kan ' $n$ grafiek gegenereer word wat elke lid se aanspreeklikheid teenoor die klub as ' $n$ funksie van tyd grafies vertoon. Laastens kan enige lid op enige stadium ' $n$ rekord trek van die aantal saamrygeleenthede wat hy oor ' $n$ bepaalde periode voorsien en ontvang het. Dit mag handig wees vir belasting doeleindes. 


\section{INTRODUCTION}

High vehicle running cost and intolerable traffic densities have forced many commuters worldwide to revert to lift clubs. While lift clubs provide an effective means of overcoming the former disadvantages, it can also be very enjoyable, provided all members are in constant agreement with the answer to the following question:

\section{Whose turn is it to drive next?}

For a number of reasons, the answer to this question is not as obvious and straightforward as one may think. Some of the reasons for this, are the following:

$\Leftrightarrow$ At times in any lift club's history, one or more members may be away on leave or on a business trip, or may simply fall ill. This will inevitably upset the normal schedule,

$\Rightarrow$ The nominee for the next trip may have an appointment to have his vehicle serviced or his spouse may need the vehicle for other purposes on the particular day,

$\Rightarrow$ Drivers may want to swap their "turns to drive" amongst one another for many reasons.

An upset in the schedule often causes confusion amongst the members, which in turn can lead to unnecessary friction. What is needed is a flexible, logical, consistent, unambiguous, unbiased and preferably paperless method, which can resolve the above question.

The formula described in this paper provides a complete solution to the scheduling problems of lift clubs. In addition, a complete log of the lift club's day-to-day operation (which may be handy for tax purposes) is available and interesting statistics such as (i) average utilization, (ii) effective size of the lift club, etc., is simple to calculate.

The proposed formula was implemented on an Excel spreadsheet and was tested in practice over a period of eight months. Not once during this period, did any of the four members of the particular lift club quarrel about the question posed above. It proved to be a very powerful scheduling tool for lift clubs indeed.

\section{FEATURES OF THE SCHEME}

The proposed scheme, has the following features:

$\Rightarrow$ It caters for any number of lift club members

$\Rightarrow$ It assumes that at least one member of the lift club possesses a vehicle and that members who do have vehicles, are willing to share it on a rotational basis with the other members of the club

$\Rightarrow$ It recommends a driver for the next trip, but is flexible enough not to force a decision

$\Rightarrow$ The lift club becomes an entity in its own right, rather than being a collection of individuals

$\Rightarrow$ It can easily be implemented in a spreadsheet such as Excel 
$\Rightarrow$ It requires the minimum administrative time and effort

$\Rightarrow$ When implemented in a spreadsheet, a number of useful and interesting statistics can be produced, such as:

- \%-utilization of individual members,

- average \%-utilization of all members,

- effective size of the lift club (less or equal to the actual number of members in the club),

- average \%-saving on transport cost, etc.

$\Rightarrow$ When implemented in a spreadsheet, reports showing each member's total number of trips, transport cost, etc. over any length of time, can be generated. Such records might be useful for tax purposes

$\Rightarrow$ When the lift club is dissolved, it will indicate the outstanding liability between the lift club and all its members, i.e. the $\mathrm{R} / \mathrm{c}$ amounts to square up the books of the lift club

$\Rightarrow$ It can cater for any possible situation and peculiarities that may arise during the course of the lift club's operation

\section{RATIONALE OF THE SCHEME}

From a philosophical point of view, it can be postulated that the primary reason people form lift clubs, is to save on transport cost by spreading the costs associated with compulsory trips, that are common to all members, on a proportional basis.

A trip is "compulsory" only if a member is obliged to undertake that trip. To illustrate, should persons who are not affiliated to a lift club be on leave, they would not suffer any travelling expenses pertaining to their work for the duration of their leave. Accordingly it would not make sense to debit a lift club member's "account with the lift club" with respect to those days that he is absent or on leave.

The word "common" is included in the above motivation to stress the fact that it is only reasonable to ask of the lift club to "subsidise" those trips that are common to all its members. To illustrate, if a person is required to make a non-standard trip (say to the airport, an outside company etc.), that trip would not coincide with the standard route of the club on which the sharing/spreading of cost (i.e. subsidising) is based. Therefore, that trip should be for the particular member's own account and should not enter the "books" of the lift club. The member making the non-standard trip will neither consume nor provide a trip on the particular day, and therefore may be treated as if he was on leave.

The word "proportional" in the motivation suggests that it is reasonable to assume that the more trips a member consumes, the more trips he should provide. If one member consumes less trips than the rest, he actually "has a smaller share in the club" (receives less subsidy from the other members) and therefore should not be required to "repay the club" to the same extent as his fellow members. Although an ideal lift club will consist of members all having an equal "share" in the club (this will lead to the maximum cross subsidization between the members of the club), this is seldom the case in practice. 
The formula that is derived in the next section hinges on the three conceptions above. It is believed that if these conceptions are honoured, all members will enjoy "a fair deal".

\section{THEORY AND LOGIC OF THE SCHEME}

Consider a lift club consisting of $n$ members which was formed at time $t=0$. Let $c_{i}(t)$ be the cumulative number of trips that member $i(i=1,2, \ldots, n)$ consumed from the club by the end of time $t=t$. Similarly, let $p_{i}(t)$ be the cumulative number of trips provided by member $i$ to the club by the end of time t. For the purpose of this discussion, forward trips (e.g. home to work) and return trips (e.g. work to home) are counted separately.

The total number of trips that the lift club offered all its members up to the end of time $t$ is

$$
C(t)=\sum_{i=1}^{n} c_{i}(t)
$$

Likewise, the total number of trips that the lift club received from all its members by the end of time $t$ is

$$
P(t)=\sum_{i=1}^{n} p_{i}(t)
$$

In general, not all the members of a lift club will utilise the lift club to the same extent. Some members will consume a higher proportion of the total number of trips offered by the club than others, and in this sense members will have a different "share" in the lift club. A specific member's share (also a function of time) may be calculated as follows:

$$
\text { Share }_{i}(t)=\frac{c_{j}(t)}{C(t)}
$$

According to the concept of proportionality explained in the previous section, a member's liability towards the club must be in relation to his share in the club. Stated differently, a member's proportional contribution towards a lift club must be equal to the proportion of benefits that he receives from the club.

From an equity point of view, let $\mathrm{P}_{\mathrm{i}}(\mathrm{t})$ be the cumulative number of trips that will balance the benefit/contribution equation for member $i$. Then

or

$$
\text { Share }_{i}(t)=\frac{c_{i}(t)}{C(t)}=\frac{P_{i}(t)}{P(t)}
$$

$$
P_{i}(t)=\frac{c_{i}(t)}{C(t)} P(t)=\text { Share }_{i}(t) \cdot P(t)
$$

Lastly, let $\Delta \mathrm{p}_{\mathrm{i}}(\mathrm{t})$ be the difference (shortfall or surplus) between the actual number of trips provided by member $i$ and the number he should have provided by the end of time $t$, then 


$$
\begin{aligned}
\Delta p_{i}(t) & =p_{i}(t)-P_{i}(t) \\
& =p_{i}(t)-\frac{c_{i}(t)}{C(t)} P(t) \\
& =p_{i}(t)-\text { Share }_{i}(t) \cdot P(t)
\end{aligned}
$$

or

$$
\Delta p_{i}(t)=p_{i}(t)-\left[\frac{c_{i}(t)}{\sum_{j=1}^{n} c_{j}(t)}\right] \sum_{j=1}^{n} p_{j}(t)
$$

The unit of measurement of the $\Delta p$ 's is number of trips. A positive $\Delta p$ indicates the number of trips the lift club owes a particular member. Conversely, a negative $\Delta p$ indicates the number of trips a particular member owes the lift club. It should be noted that

$$
\sum_{i=1}^{n} \Delta p_{i}(t)=0
$$

Equation 1 provides the means for scheduling a lift club. At the end of each day, the $\Delta p$ 's are calculated for all the members. The member having the most negative $\Delta \mathrm{p}$ at the end of a particular day (or lift club operation) should strive to render the next service (on the following day or next occasion). The $\Delta \mathrm{p}$ 's are thus used as scheduling indices. Should it be possible in practice to exactly keep to the schedule (this will never be the case), then theoretically the indices of members should not drift far below or above -1 and +1 respectively. The amount by which a member's index is below 1 , is an indication of how overdue that member is for providing the next trip.

The $\Delta \mathrm{p}$ 's can easily be converted into a distance $(\mathrm{kms})$ by multiplying it with the trip distance. This product would indicate the liability between a member and the lift club in terms of number of kilometers. If this product is multiplied by the agreed running cost per kilometer, then the liability between the lift club and its members are known, and can be expressed, in monetary terms.

$$
\begin{aligned}
& \text { Liability of Member/Lift club towards Lift club/Member } \\
& =\text { Member's } \Delta \mathrm{p} X \text { Running cost } / \mathrm{km} \text {. X Trip distance }
\end{aligned}
$$

\section{IMPLEMENTATION OF THE SCHEME}

It is highly recommended that equation 1 be implemented on a spreadsheet such as the one shown in figure 2. Although this sheet is for a lift club with only two members, it can be expanded to cater for any membership number. The sheet has a title, a header row containing specific data applicable to the lift club, a body where most of the calculations are done and a section for the statistics. In the following paragraphs, the individual sections of the sheet will be explained briefly. 
Title:

The title of the sheet indicates the schedule period. Use this for bookkeeping purposes to distinguish between the schedules of successive periods.

\section{Header row:}

The header row contains four important data items, namely:

$\Leftrightarrow$ Running cost per kilometer. When the lift club is dissolved, some members will end up with a debit balance (they will owe the lift club a certain amount of trips, which can be converted into monetary terms) while others will have a credit balance (the lift club will owe them a certain amount trips/money). This mutually agreed figure is only used to square up the books of the lift club when it is dissolved. In the example of figure 2 , the lift club agreed on a value of R0,27.

$\Rightarrow$ Trip distance. This is the distance between the origin and the destination of the lift club's route, taken in one direction only (e.g. home to work or work to home). In the example of figure 2, the trip distance is $60 \mathrm{~km}$. This specific lift club will therefore travel 120 kilometers per day.

$\Rightarrow$ Number of members in the lift club. This is the size of the lift club. In the example of figure 2, the lift club has two members, Mike and Chris

$\Rightarrow$ Date printed. This is the date on which the specific copy of the schedule was printed.

\section{Body:}

This is the main portion of the sheet where the actual calculations take place.

Reading the sheet from left to right, the first two columns are used to indicate the date and weekday of each day in the month. Although the example sheet of figure 2 also shows weekend days (i.e. Saturdays and Sundays), this is not necessary. Only lift club operation days need to be reflected on the sheet. It is advantageous to use a standard sheet catering for a 31-day month and to use this for all months of the year.

The above two columns are followed by a set of five columns for each lift club member. In the example sheet of figure 2, the first two columns of a member are used to indicate the number of trips that member consumed. The first of these shows the number of trips the member consumed on each day of the schedule period. The second column shows the cumulative number of trips (since the inception of the lift club) the member consumed up to and including the row date. In exactly the same way, the last two columns of each member are used to indicate the number of trips he provided. The first of these pertains only to the row date itself, while the second indicates the cumulative number of trips provided. The middle column reflects the member's \%-share in the lift club calculated as the ratio of his cumulative number of trips consumed and the overall cumulative number of trips consumed by all members up to the current point in time (see equation 1). Only columns one and four of each member requires input data. All other columns of the sheet are calculated automatically. In column 1 the lift club administrator must enter a figure indicating how many trips the member consumed on the day pertaining to the row-date. For a two-way trip a figure of " 2 " must be entered. For a one-way trip a figure of " 1 " must be entered. If the member did not use the lift club on a particular day, a " 0 " may be entered or the cell may be left blank or a short descriptive reminder may

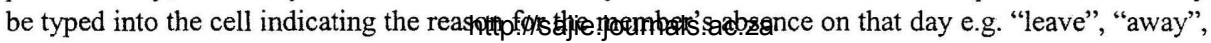


etc. This will not influence the integrity of the numerical calculations within the sheet. Column 4 is used to $\log$ the trips provided on a particular day. Normally only one member will be the official nominated driver on a particular day. This member will normally provide the forward as well as the retum trip in which case a " 2 " must be entered in his column 4 on that day. It should be noted that the nominated driver would both consume " 2 " trips from and provide " 2 " trips to the lift club on the same day. In larger lift clubs, various peculiar permutations are possible. For instance one member may be nominated as the official driver on a particular day, while another may for some reason wish to go to work in his own vehicle. The nominated driver may offer the forward trip, but may be incapable of providing the return trip due to work pressure that he was unaware of beforehand. If it is possible for the other member that went to work in his own vehicle to provide the return trip (to the other lift club members), then both he and the nominated driver will have provided one trip each on that day and each will be credited with a " 1 " in their respective fourth columns on that day. The total number of trips provided on any one day may not exceed the value "2". NOTE: Only the data of columns one and four of a member need to be manually entered. All other columns of the sheet are automatically calculated. This operation only takes a few minutes per day.

The fifth column of the last lift club member is followed by two columns. The first of these contains a running total of the cumulative number of trips consumed by all the members up to the corresponding row dates. This column is obtained by adding the cumulative number of trips consumed by each member over all the lift club members. The second column does exactly the same for trips provided, in other words it represents a running total of the cumulative number of trips provided by all members.

The columns described thus far contain all the information necessary to enable the calculation of the indices using equation 1 .

The last (two in the case of this example) columns of the spreadsheet are the crux of the scheme, and indicates, through a set of indices (one for each member of the club),

\section{whose turn it is to drive next.}

When new trip data is entered (i.e. trips provided and consumed for each member on a specific day) the spreadsheet will automatically update the indices for all the lift club members. The relative values of these indices at the end of the current day are used to nominate a driver for the next day. Preferably, the member having the most negative index (at the end of each day there will always be at least one member having a negative index) should be the driver on the next day. If for some reason he cannot provide this service, the member with the second smallest index (this index may be positive) should be nominated, and so forth. If this scheme is followed, the system will automatically level out the members' liabilities towards the lift club. In this way the situation is avoided where one member falls so far behind that it later becomes impossible (or extremely difficult) for him to catch up.

\section{Note:}

The first row of the sheet of figure 2 has a special purpose. It is used to transfer the cumulative number of trips consumed and provided for each member from the last row of the previous sheet to the current sheet in order to preserve continuity of the trip history from one month to the next. Initially, there will be no previous month from which to carry totals forward. All the entries in the first row of the first month's sheet must therefore be set equal to zero (or left blank). 


\section{OPERATION OF THE LIFT CLUB}

The schedule of figure 2 starts on Sunday 25 July with Mike having a negative index of -1.79 and he volunteered to drive on Monday the $26^{\text {th }}$. At the end of this day, Mike's index was still negative and therefore he also drove on Tuesday the $27^{\text {th }}$. Now Chris's index became negative $(-0.19)$ therefore he provided the trip on Wednesday. The two members kept on following the schedule precisely up to the end of the second week (i.e. Friday the $6^{\text {th }}$ of August) at which stage Chris's index had a negative value of -0.13 . Although Chris was supposed to drive on Monday, he had put in leave for the first three days of the next week and thus could not do so. Mike kept on driving on his own and ended up with a relatively high positive index on Wednesday the $11^{\text {th }}$ of August. Now Chris was back, he provided the next two trips and his index was positive again at the end of Friday 13 August. Mike provided the next to trips on Monday and Tuesday of the following week and ended up with a positive index of 0.21 . For the next two days Mike went on a business trip and was due back only on Friday morning about 11h00. On Wednesday and Thursday Chris drove on his own. Although Mike's index was negative at the end of Thursday 19 August, he could not provide a trip on Friday because of his expected late arrival on this day. Chris on the other hand, intended to leave early on Friday and therefore he too could not officially represent the lift club on that day. Both members therefore used their own vehicles in their private capacities on Friday the $20^{\text {th }}$ August, which now has lost the status of an official lift club operation day. Up to Thursday of the next week, the members again strictly followed the schedule at which stage Mike's index had a negative value of -0.60 . Mike however could not offer a trip on Friday 27 August because his vehicle was due for a service. Chris therefore offered to provide the trip. Notwithstanding the many deviations from the proposed schedule during the course of the month, the two members still ended up with indices that were on par at the end of the month.

A graph of the two indices of figure 2 is shown in figure 1. Because the sum of the members' indices must be zero, the two indices of a two-member club will always be mirror images of each other. The normal index-pattern is the typical zigzag pattern that is seen during the first few days in figure 1. Any upsets in the schedule are reflected by a deviation from this normal pattern. The ability of the scheduling scheme to handle such upsets is clearly illustrated by figure 1 through the fact that the indices are constantly forced towards the zero line.

LIFT CLUB STATUS REPORT - July/August 1997 (All members)
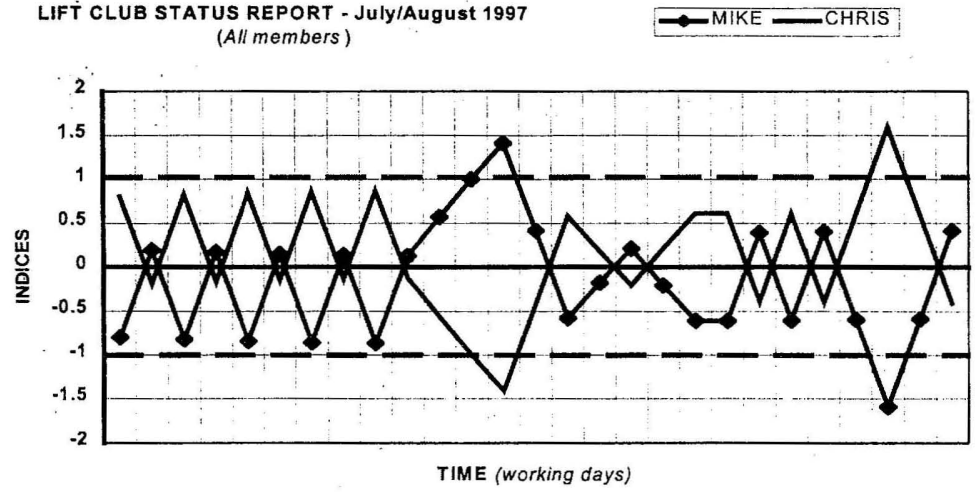

Figure 1. Graph of the two indices of figure 2. 
Figure 2 also contains a table of interesting statistics. The effective size of this 2 -member lift club is 1.7. Thus far, the members enjoyed an average saving on transport cost of $41 \%$. Chris enjoyed a substantially higher saving on transport cost during the last scheduling period than Mike $(47,6 \%$ versus $37.5 \%$ ), etc.

Another aspect worth mentioning is the following. Two members may end a scheduling period having more or less the same index values, but one may have been in debt for most of the scheduling period and may only have managed to restore his position towards the end of the period (by providing a quick number of trips in succession). The average values of the indices over the scheduling period (also shown in figure 2) are used to indicate such tendencies. Due to the "time value of money" concept, this type of situation should be avoided. The average values of the individual members' indices should therefore also be of a comparable magnitude.

The remainder of this section addresses some diverse issues that are regarded as important for the successful operation of a lift club.

a) Although not essential, it is preferable that the members of a newly formed lift club reach agreement/consensus on the following:

$\rightarrow$ Decide on a standard running cost per kilometer traveled. This could include fuel, normal wear and tear, licenses etc. In general, the running cost of individual members' vehicles would be different, and therefore the best solution is to decide on an average. When the lift club is dissolved, the agreed running cost should be used "to close and balance the lift club's books". In practice this will require a quick calculation to determine how much, members ending with a negative index, owe the lift club, and how much the lift club owes members having a positive index on the last day. This calculation is straightforward and is described in section 7 of this paper.

$\rightarrow$ Decide on a standard trip distance. This should be the distance of that portion of the lift club's route that is "common" (refer to section 4) to all the members.

b) If possible, appoint one member to administer the system. This person should preferably have access to a PC and be familiar with spreadsheets. The lift club may wish to rotate this responsibility, however, in view of the simplicity and small effort required, it is better to appoint one volunteer for the job. The nominee should familiarize himself with the scheme and should also be willing to explain its philosophy to the other members so that everybody will understand and trust the system.

c) Once a week (e.g. on a Friday), a tentative schedule should be drawn up for the following week. This involves a simple "simulation process" and is done on a day-by-day basis as follows: The member with the most negative index at the end of the current week is scheduled to drive first. Enter a "2" in this member's fourth column. Enter the number of trips each member of the lift club is expected to consume on this first day. For single trips a value of " 1 " should be entered in the first column of the relevant members. For trips in both directions a "2" should be entered. Once the trip data for this first day of the next week has been entered, check the indices of all members to see who should drive next. Then proceed as before to fill in the trips consumed and provided for the second day of the next week. Repeat this process until the schedule reflects the drivers for all working days of the next week. This exercise should not take more than about three minutes on a computer using a spreadsheet. The administrator can print the schedule and hand each member of the lift club httpopy thereof The hard copies serve a dual purpose. Apart 
from the fact that the schedule will point out on which day in the coming week each member is suppose to drive, members can use it to check whether their data of the past week had been entered correctly. If not, the administrator must correct the schedule and preferably hand out an updated version thereof to the members of the club. Deviations from the anticipated schedule will however often occur. While drivers should try to adhere to the generated schedule as close as possible, they can freely exchange their turns to drive with one another. All deviations from the previous schedule must be amended in the next schedule. Once a year the administrator may want to give each member a copy of the schedules for the preceding twelve months. This may come in handy for tax purposes.

d) Members should try to adhere to the weekly schedules as closely as possible. This will prevent certain members from falling so far behind in the provision of trips to the lift club, that they may later find it difficult to eliminate their debt. The inherent freedom and flexibility of the scheme could thus become an obstacle if proper discipline is not applied.

e) When one or more members join and/or leave the lift club, the existing club must be dissolved and reformed from scratch. A new form must be drawn up reflecting the name(s) of the new member(s), and the cumulative totals in the first row of the first sheet must be reset to zero. If this is not done, the scheme has the inherent tendency to penalize the new member(s) by requiring of them to repay a proportion of the historical trips of the club. This of course would be unfair to the new member(s), for they had not shared in the past benefits of the club.

f) Although it is preferable for each person belonging to a lift club to have a vehicle of his own that he can use to provide trips to the club on a rotational basis, the odd situation may arise where this is not possible. However, members not having their own vehicles, can be accommodated and basically be treated in exactly the same way as the rest. They also consume and "provide" trips, but instead of using their own vehicles, they "rent" one of the other members' vehicles (on a random or rotational basis) on those days that it is their turn to provide the lift. On a particular day, the member providing the trip must physically pay the owner whose vehicle he uses to provide the trip, a sum of money, which is calculated as follows:

\section{Total kilometers traveled on the day $\mathrm{x}$ Running cost $/ \mathrm{km}$}

In general, the distance in the above formula will be greater than the trip-distance, because the owner of the vehicle will have to be remunerated for collecting the member renting the vehicle at his home. The above distance therefore is the distance between the home of the member whose vehicle is used and the lift club's destination. In the case of a two-way trip, the last distance should be doubled. The owner will probably still insist on driving his own vehicle, but for all practical purposes that trip is provided by the member who "rented" the vehicle on that day. The trip-data must reflect the fact that the trip(s) was provided by the member that rented the vehicle. The Running cost used in the above formula may also differ from the standard running cost of the lift club, although this is not recommended. Finally, it is recommended that all members having vehicles should take turns to rent out their vehicles to those members not having vehicles.

h) Lastly, although it is theoretically possible to operate the scheme without the assistance of a PC, it really only comes to its full right when implemented on a spreadsheet. This is the recommend way to implement and operate the scheduling scheme. 


\section{TERMINATION OF THE LIFT CLUB}

Usually when the lift club is dissolved, certain members will have positive indices while other members' indices will be negative. If there is a large discrepancy between the largest positive and negative indices, equation 2 can be used to balance such differences. A member having a negative index, will be required to pay the lift club a certain amount of cash. Similarly, the lift club will owe a member whose index is positive, a certain amount of cash. Because the sum of the indices will always be equal to zero, the above procedure actually causes those members with negative indices to repay their outstanding debt to the members having positive indices. The spreadsheet in figure 2 provides these amounts as part of its standard output. A large monetary debt is a far stronger motivator than a negative index to inspire an under-performer to bring his side.

\section{CONCLUSION}

The ability of the simple formula and scheduling scheme presented in this paper to cater for the specific needs of a lift club is remarkable. It possesses all necessary attributes that were listed in section 1 , namely:
$\Rightarrow$ it is flexible
$\rightarrow$ it is logical
$\Rightarrow$ it is consistent
$\Rightarrow$ it is unambiguous
$\Rightarrow$ it is unbiased
$\Rightarrow$ and when implemented in a spreadsheet, the scheme is almost paperless

The fact that the indices, as defined by equation 1, have a direct monetary interpretation (according to equation 2), serves as an indication that this might be the ultimate scheduling scheme for lift clubs.

The possible application of equation 1 to a wider range of Industrial Engineering problems with similar characteristics would be interesting and should be investigated.

Happy travelling!! 